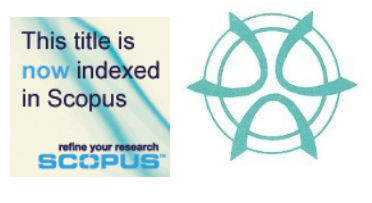

PLANNING MALAYSIA:

Journal of the Malaysian Institute of Planners

VOLUME 18 ISSUE 2 (2020), Page 59 - 72

\title{
RISK COST ANALYSIS IN MALAY HERITAGE \\ CONSERVATION PROJECT
}

\author{
Nurul Hadirah Mohd Nawi ${ }^{1}$, Roziha Che Haron ${ }^{2}$ \& Zumahiran \\ Kamarudin $^{3}$ \\ 1,2,3 Kulliyyah of Architecture and Environmental Design \\ INTERNATIONAL ISLAMIC UNIVERSITY MALAYSIA
}

\begin{abstract}
Risks in conservation projects are believed to be different from risks in new building projects. There are different methods and processes that need to be adopted in order to handle a conservation heritage project. Heritage projects form a valuable inheritance with sentimental values that tell a certain history, culture or tradition which needs to be preserved. Nevertheless, many have reported that conservation projects frequently suffer failures in meeting the delivery goals of time, quality and budget, which lead to contractual disputes during the postcontract stages of a conservation project. Conservation work is riskier due to the inclusion of many activities such as preservation, restoration, and refurbishment. Thus, this research aims to identify the risk cost analysis in carrying out conservation projects through conducting semi-structured interviews and using the survey research method. The objectives are to highlight the importance of conserving Malay heritage and identify risk affecting cost of conserving heritage buildings. This research applied strategy survey through semi-structured interview and questionnaire survey. It was found that project risk consists of hidden works and uncertainties is the highest among other risk categories. The outcome of this research is considered to be significant and relevant as it contributes towards the conservation sector by minimising the risk of cost analysis taken on conservation projects by the project team involved.
\end{abstract}

Keywords: Conservation, heritage project, risk

\footnotetext{
${ }^{1}$ Postgraduate Student at International Islamic University Malaysia. Email: nuhadirah@gmail.com
} 
Nurul Hadirah Mohd Nawi, Roziha Che Haron, \& Zumahiran Kamaruddin

Risk Cost Analysis in Malay Heritage Conservation Project

\section{INTRODUCTION}

Construction project is not simply restricted to the new buildings only but it also includes restoration and maintenance of existing building. Heritage can be one of the whys and wherefores. The National Heritage Department (2016) defined heritage as a valuable inheritance that can be categorized under tangible and intangible components.

A construction project can be considered successful or not through project management triangle; time, cost and quality. Roy and Kalidindi (2017) has unfortunately reported that for conservation project, the performance in terms of time, quality and especially cost is far from satisfactory. Bowen et al. (2002) claimed that neglecting any one factor would affect other two factors. This shows that factor of cost for conservation project is important to be highlighted in order to prevent delay and low quality of the conservation project. Currently, the industry is facing several issues that have caused cost and time overruns and also contractual disputes during post-contract stage (Lee \& Lim, 2010; Hisham \& Hassan, 2015). Surprisingly there are actually many countries facing the same difficulties when dealing with heritage building. Roy and Kalidindi (2017) said that Canada, Italy, Australia and India are some of the countries that reported frequent failures in meeting the delivery goals of time, quality, scope and budget.

One of the factors of failing to reach the budget of conservation project is because of limited research on costing aspect of conservation project (Hisham \& Hassan, 2015; Wee \& Lim, 2010). Kamal et al. as cited in Wee and Lim (2010) explained reason for limited research on costing aspect of conservation works is because building conservation practice in Malaysia is relatively new compared to some other countries. This is supported by Lim (2017) where he claimed that conservation processes may be broadly studied by researcher, however, the same cannot be said for the cost management aspect, namely cost control, cost budgeting and cost estimating. This shows that more research on costing of conservation project must be performed so that issues on cost overrun that often occur in the project can be successfully prevented and solved.

Lack of complete costing information for conservation project causes consultants to face difficulty in preparing cost budget for conservation projects (Hisham \& Hassan, 2015; Wee \& Lim, 2010). The absence of costing information, together with lack in understanding by consultants on nature of conservation project tends to result in missing important items related to conservation project during estimating budget. Wee and Lim (2010) are another author that also agreed there is still lacking in costing information and documents pertaining to conservation work. They are having difficulty in collecting data for their research as only a total of 16 buildings can be selected since many projects have incomplete breakdown of costing information, as some projects did not follow the full tendering procedures. 
Thus, it is important to determine project risks that influence cost of conserving heritage building in order to protect our Malay heritage. Therefore, the objectives of the research are; 1) to highlight the importance of conserving Malay heritage and 2) to identify risk affecting cost of conservation of heritage buildings.

\section{MALAY HERITAGE}

Ariffin, Dodo, Nafida and Kamarulzaman (2015) added that the World Heritage Convention defines heritage as 'monuments, groups of buildings and sites. The National Heritage Act 2005 implemented in the ninth Malaysia Plan was to provide protection and conserve various tangible and intangible cultural heritages and was promoted for the tourism industry. From the Kuala Lumpur Structure Plan 2020, it is reported that areas with an attractive character and strong sense of identity need to be preserved and enhanced and, where possible, other areas need to be upgraded to provide an enhanced sense of identity and place. Bachek, Zainudin and Haron (2014) said that this include historical and heritage buildings.

Rashid et al. (2018) found in their study that traditional Malay houses in Perak located along the Sungai Perak are old Malay palaces, traditional houses and mosques. In addition, colonial architecture also is primarily found in several towns along the river, such as Kuala Kangsar, Parit, Bota, Pasir Salak, Kampung Gajah and Teluk Intan, including houses, schools, offices, rest houses, mosques and hospitals which are still in use until today.

In short, Malay heritage is important as it maintain the history and belief of society, protect significance of architecture and culture, portrays value of historical building, shows image and identity of the city, and provide continuity and stability in built environment.

\section{CONSERVATION WORKS}

Roy and Kalidindi (2017) and Hisham and Hassan (2015) define heritage conservation as all the processes by which a place is cared for in order to retain its historical and/or architectural and/or aesthetic and/or cultural significance, including the maintenance, preservation, restoration, reconstruction and adoption or combination of more than one of them. Ali, Kamaruzzaman, and Salleh (2009, p.56) explain that "refurbishment refers to upgrade, major repairs work, renovations, alterations, conversions, extensions and modernization of existing building, but exclude routine maintenance and cleaning work". Meanwhile, Zolkafli et al. (2012) added classification of conservation projects can divided into difference categories, which are preservation, restoration, rehabilitation, and refurbishment.

According to Article 8 of Burra Charter by ICOMOS (2003), 'new construction, demolition, intrusions or other changes which would adversely affect the setting or relationships are not appropriate.' If the activities such as 
Nurul Hadirah Mohd Nawi, Roziha Che Haron, \& Zumahiran Kamaruddin

Risk Cost Analysis in Malay Heritage Conservation Project

preservation, refurbishment or reconstruction, is performed with the intention to keep and build back the originality of the building, it is considered as one of the conservation projects.

In a nutshell, conservation project is different from the new building project in terms of scope of work, nature and principle of the work. Conservation project is believed to be riskier than new building project. This is because conservation work required non-standard scope of works, different approaches and special project management experience. Moreover, conservation project tends to be riskier as so much care must be done in terms of material and skills workmanship in order to maintain the building authenticity.

\section{COSTING IN HERITAGE CONSERVATION PROJECT}

Managing cultural heritage assets, such as building heritage, is considered expansive and expensive for some people, which is usually funded by government or private institution (Ismail, Masron \& Ahmad, 2014). In Malaysia, the Ministry of Information, Communications and Culture (KPKK) is responsible for national heritage.

Smith (2005) explains that in planning of a conservation works, it involves different stages, scope and timing of the proposed work, which requires a budget. It is complex and difficult to prepare estimates for conservation work due to the difficulties to predict the nature of such work in terms of the final content, scope and specification. In addition, the exact work can be known only after the structure is open and demolished. Structures of existing old building is one the major factors that determine a project overall cost. Nevertheless, mechanical and electrical work costs are often high because of the complex nature of the installed systems.

Thus, by understanding the major factors that determined the budget in conserving a building, a quantity surveyor will ensure work-specific items to be included in the tender which lead to a better cost estimate.

\section{RISK IN MALAY HERITAGE CONSERVATION PROJECT}

Conservation work involved risks where Zolkafli et al. (2012) believe that risks in conservation project are actually much higher than new building project. Game, Fitzsimons, Lipsett-Moore \& McDonald-Madden (2013) mention that "understanding risks to project success should influence a range of strategic and tactical decisions in conservation, and yet, formal risk assessment rarely features in the guidance or practice of conservation planning". Risk management in conservation projects had been poorly practiced and applied nowadays (Zolkafli et al., 2012).

Risk is defined as uncertain event or condition, which has negative effect on the successfulness of project objective if it, occurs (Mbachu \& Taylor, 2014; Rezakhani, 2012; Safayet, Hamidul Islam \& Shakil Ahmed 2018; Zolkafli 
et al, 2012). Therefore, risk is an exposure to economic loss or gain arising from involvement in the Malay heritage construction project.

Risk assessment will prioritize which risks need to be managed in Malay heritage conservation project. An appropriate and systematic methodology, knowledge, and experience will be demanded in order to have an effective and proper risk management approach (Safayet, Hamidul Islam \& Shakil Ahmed, 2018).

There are six categories of risk in Malay heritage conservation project as highlighted in Table 1. This can be identified before and during construction (Safayet, Hamidul Islam \& Shakil Ahmed, 2018). Construction project is associated with many risks affecting the cost of a project including conservation project.

Table 1: Risk categories

\begin{tabular}{cl}
\hline Risk & \multicolumn{1}{c}{ Description } \\
\hline Project & $\begin{array}{l}\text { In Malay heritage conservation project, uncertainties are common such as } \\
\text { hidden work or unforeseen items as project team cannot find out the detail } \\
\text { of certain part of historical building without opening it. }\end{array}$ \\
\hline Design & $\begin{array}{l}\text { Design risks might arise such as design error or discrepancies due to } \\
\text { limited and inaccurate information regarding the original design. (Safayet, } \\
\text { Hamidul Islam \& Shakil Ahmed, 2018) }\end{array}$ \\
\hline Material & $\begin{array}{l}\text { Availability of the identical of original material for construction is one of } \\
\text { the challenges in Malay heritage conservation work. }\end{array}$ \\
\hline Cabour & $\begin{array}{l}\text { Some of the buildings might use services of talented artists when it was } \\
\text { first built. In order to re-produce the crafts, similar skilled artists need to } \\
\text { be hired but very hard to find. }\end{array}$ \\
Financial & $\begin{array}{l}\text { Risks in capital investment, government taxes and materials price must be } \\
\text { considered especially in a long-term project due to inflation and other } \\
\text { factors. }\end{array}$ \\
\hline Human risk & $\begin{array}{l}\text { Successful of conservation project largely depend on the professionalism } \\
\text { of the project team. Barnes (as cited in Xiang, Jia \& Li, 2018) observed } \\
\text { that human risk factors must be taken seriously. }\end{array}$ \\
\hline
\end{tabular}

\section{RESEARCH METHODOLOGY}

This study focussing on risks affecting cost of conserving Malay heritage buildings. In conducting this study, the authors applied strategy survey through semi-structured interview and questionnaire survey. The authors selected construction professionals whom understand and knowledgeable in a conservation project whom consist of Architect The questionnaires are given to 360 participants. From a total of 360 questionnaires, only 126 respondents returned the questionnaire with proper answer which represents $35 \%$ of response rate. The authors selected construction professionals whom understand and knowledgeable in a conservation project whom consist of Architect (33\%), 
Nurul Hadirah Mohd Nawi, Roziha Che Haron, \& Zumahiran Kamaruddin

Risk Cost Analysis in Malay Heritage Conservation Project

Quantity Surveyor (14\%), Building Surveyor (17\%) and Town Planner, Engineer $(15 \%)$. The tabulation of data as per Figure 2.

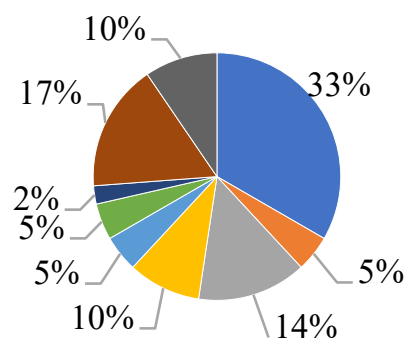

\begin{tabular}{|lll|}
\hline Architect & $\square$ Assisstant Architect \\
$\square$ Building Surveyor & $\square$ Conservator & Engineer \\
$\square$ Technical Expert & $\square$ Academician & $\square$ Town Planner \\
\hline
\end{tabular}

Figure 1: Percentage of respondents by occupations

For the results from the questionnaire, Statistical Package for the Social Sciences (SPSS) is used to analyse the data. The data is analysed through descriptive statistics. Rank for risks concerned in conservation project is obtained using reliability analysis in the SPSS. Ranking the risks is important in order to measure the crucially of each risk in conservation project.

Statistical Package for the Social Sciences (SPSS) is used to analyse the data through descriptive statistics. Rank for risks concerned in conservation project is obtained using reliability analysis in the SPSS. This is in order to measure the crucially of each risk in conservation project.

The result is then validated through semi-structured interview with a quantity surveyor, two conservators, a building surveyor and a heritage coordinator who have more than 10 years experiences in conservation of heritage buildings.

\section{ANALYSES AND DISCUSSION}

Malay heritage is related to the way of life of Malays society. The way of life is how it differentiates Malays with other races. Panel 05 mentioned that religion, culture, location, geographical, and also hierarchy affect the way of life. Different forms and spaces are created because of the way we live. In addition, it supports literature when she said that Malay heritage is important to protect the history, culture of Malays, and for tourism.

In the questionnaire, there are 7 categories of risks expressed including identified and collected from literature review; project risk, design risk, material risk, labour risk, financial risk, human risk and data risk. Under each of the 
category, there are various example of risks can be found as illustrates in Table 2 ;

Table 2: Lists of risk under different risk categories.

\begin{tabular}{|c|c|}
\hline Category & Risk \\
\hline Project risk & $\begin{array}{l}\text { 1. Hidden works } \\
\text { 2. Uncertainties }\end{array}$ \\
\hline Design risk & $\begin{array}{l}\text { 1. Hidden work found during construction causes design to be } \\
\text { changed or modified } \\
\text { 2. Changes of original design because of funding constraint. } \\
\text { 3. Design information are vague and inaccurate. }\end{array}$ \\
\hline Material risk & $\begin{array}{l}\text { 1. Unavailability of material needed. } \\
\text { 2. Limited availability of original type of materials. } \\
\text { 3. Alternative material used caused heritage building to lose its } \\
\text { value. }\end{array}$ \\
\hline Labour risk & 1. Unavailability of workmanship needed. \\
\hline Financial risk & $\begin{array}{l}\text { 1. High cost for using original and authentically materials and } \\
\text { components. } \\
\text { 2. Large amount of money spend on variation. } \\
\text { 3. Inadequate or insufficient funding. } \\
\text { 4. High payment on skilled artist. } \\
\text { 5. Unavailability of reliable historic cost information. }\end{array}$ \\
\hline Human risk & $\begin{array}{l}\text { 1. Limited knowledge of consultant, expertise and specialist in } \\
\text { conservation project. } \\
\text { 2. Contractor's poor capability. } \\
\text { 3. Miscommunication between parties. } \\
\text { 4. Contractor price items without performing site survey or only } \\
\text { based on assumption }\end{array}$ \\
\hline Data risk & $\begin{array}{l}\text { 1. Missing and lack of related documents. } \\
\text { 2. Uncooperative parties during collecting data and information. } \\
\text { 3. Tender document is confusing due to lack of critical } \\
\text { information. }\end{array}$ \\
\hline
\end{tabular}

\section{Hidden works}

Hidden works in conservation might affect the design process, which then affects the performance of conservation project in terms of cost. The design is changed during construction if there is a discovery of new information or hidden works in the existing building. Usually in conservation project, hidden works causes variation order. On the other hand, in new building project, the variation order 
Nurul Hadirah Mohd Nawi, Roziha Che Haron, \& Zumahiran Kamaruddin

Risk Cost Analysis in Malay Heritage Conservation Project

can be due to changes in client's need, advance in technology, or additional design effort by architect.

\section{Inadequate and insufficient funding}

Conservation project is also exposed to risk of insufficient funding. Due to funding constraint, client and project team might have to change their decision such as choice of originality material used for the project.

\section{Uncertainties}

An uncertainty in conservation project can only be viewed once the construction works start. Conservation project is riskier than new project. This is because of the existing structure of the historical building. Repairing structure of a building required client to spend large amount of money. And would lead to additional cost. Uncertainties also relate to hidden work. Hidden work is one of uncertain items that might or might not appear in conservation project. Consultants are required to do precise assumption during design stage until completion of work to minimize risk of uncertainties in a project.

\section{Unavailability of materials and skilled labours}

There is always risk of unavailability of original material and skilled labour since historical buildings are hundreds of years old. They might not be available due to the sources of the material and skill is extinct. Cost will increase when contractor needs to import material from foreign country.

They cannot simply change it without any valid reason, as they must bear in mind to maintain the authenticity of the building. However, there is a tendency to loss building value if project team use different material from the original since the authenticity of the building lay in the material itself. Preserving authenticity of heritage building is another reason conservation is riskier than new building project. Respondent 21 said that 'even renovation is challenging enough, let alone conservation work'. Similar to new building project, chosen of material for renovation work can be decided by building owner. However, just to know materials to be used for conservation project, there must be test and research conducted which also required money.

\section{Poor performance by parties involved}

Most of the QS consultants are inexperienced in conservation construction due to limitation numbers of conservation project. Thus, the tender document is confusing due to lack of critical information.

Figure 2: Mean of risks 
PLANNING MALAYSIA

Journal of the Malaysia Institute of Planners (2020)

Mean

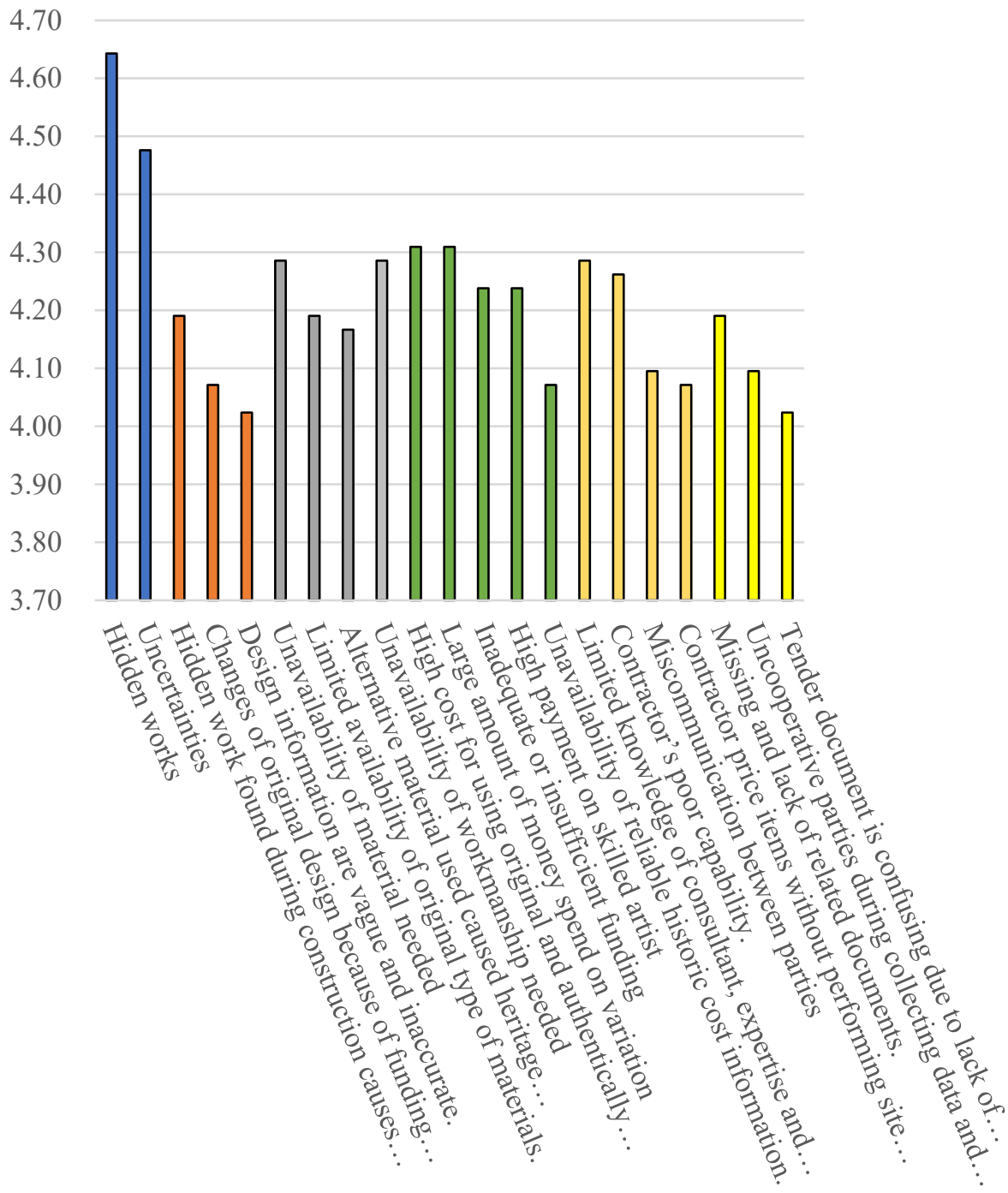

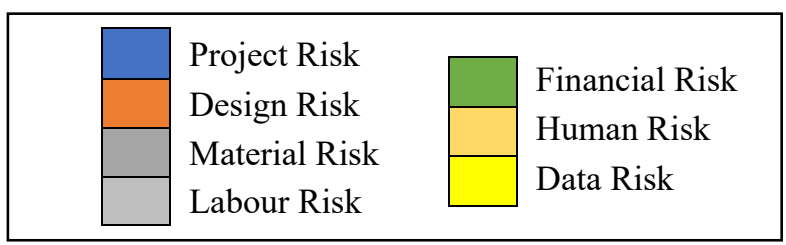


Nurul Hadirah Mohd Nawi, Roziha Che Haron, \& Zumahiran Kamaruddin

Risk Cost Analysis in Malay Heritage Conservation Project

Table 3: Top risks concerned by respondents

Risks in Malay Heritage Conservation Project Mean Rank

\begin{tabular}{lll}
\hline Hidden works. & 4.6429 & 1 \\
\hline Uncertainties. & 4.4762 & 2 \\
\hline $\begin{array}{l}\text { High cost for using original and authentically materials and } \\
\text { components. }\end{array}$ & 4.3095 & 3 \\
\hline
\end{tabular}

\begin{tabular}{lcc}
\hline Large amount of money spend on variation. & 4.3095 & 3 \\
\hline Unavailability of material and workmanship needed. & 4.2857 & 4 \\
\hline $\begin{array}{l}\text { Limited knowledge of consultant, expertise and specialist in } \\
\text { conservation project. }\end{array}$ & 4.2857 & 4 \\
\hline Contractor's poor capability. & 4.2619 & 5 \\
\hline Inadequate or insufficient funding. & 4.2381 & 6 \\
\hline High payment on skilled artist. & 4.2381 & 6 \\
\hline $\begin{array}{l}\text { Hidden work found during construction causes design to be } \\
\text { changed or modified. }\end{array}$ & 4.1905 & 7 \\
\hline $\begin{array}{l}\text { Missing and lack of related documents. } \\
\text { Limited availability of original type of materials. }\end{array}$ & 4.1905 & 7 \\
\hline $\begin{array}{l}\text { Alternative material used caused heritage building to lose its } \\
\text { value. }\end{array}$ & 4.1667 & 8 \\
\hline Miscommunication between parties. & 4.0952 & 9 \\
\hline Uncooperative parties during collecting data and information. & 4.0952 & 9 \\
\hline $\begin{array}{l}\text { Changes of original design because of funding constraint. } \\
\text { Unavailability of reliable historic cost information. }\end{array}$ & 4.0714 & 10 \\
\hline $\begin{array}{l}\text { Contractor price items without performing site survey or only } \\
\text { based on assumption. }\end{array}$ & 4.0714 & 10 \\
\hline $\begin{array}{l}\text { Design information are vague and inaccurate. } \\
\text { Tender document is confusing due to lack of critical } \\
\text { information. }\end{array}$ & 4.0238 & 11 \\
\hline & 4.0238 & 11 \\
\hline
\end{tabular}

There is problem arise in some of the Malay heritage conservation projects because of the contractor who prefer not to follow specification provided. Generally, contractor bids document without properly understand especially related to the conservation work report. Conservation project has a different skill sets demand. However, project team handles Malay heritage conservation project the same as new building project which actually required different skill sets, then problems will arise along with the risk. 


\section{CONCLUSION}

One can see that conservation project is different compared to new building project in terms of principles, processes, and procedures. But similar to new building project, conservation project also confronts and deals with risk. The risks consist of project risk, design risk, cost risk, and etc. Respondents from questionnaire survey agreed that project risk is most crucial to be addressed in conservation project. This is also agreed in validation with conservation professionals. Under category of project risk, there are risk of uncertainties and hidden work. Literatures by other authors also claimed that conservation project has a lot of uncertainties compared to new building project. A newly found risk in this research is the risk of no real value and return from historical building.

Conservation is a process of protecting the authenticity and originality of a Malay heritage building. Thus, risk of losing building value of this Malay heritage building is expected to be mostly concerned by key players compared to other risks in conservation project. However, result shows otherwise. Therefore, a study on the significance of Malay heritage building value to parties in conservation project can be performed by future researcher.

\section{ACKNOWLEDGEMENTS}

This study is funded under Fundamental Research Grant Scheme (FRGS RACER 19058 - 0058), provided by the Ministry of Higher Education and International Islamic University Malaysia. The researchers would also like to thank all respondents for their contributions in this research.

\section{REFERENCES}

Ali, A. S., Kamaruzzaman, S. N., \& Salleh, H. (2009). The characteristics of refurbishment projects in Malaysia. Facilities, 27(1/2), 56-65. doi:10.1108/02632770910923090

Ariffin, S. A. I. S., Dodo, Y. A., Nafida, R., \& Kamarulzaman, N. (2015). A Conceptual Framework for Digitalizing Tangible Heritage in Malaysia. Jurnal Teknologi, 77(16).

Bachek, S. H., Zainudin, H., \& Haron, N. A. (2014). Preservation of Culture and Built Heritage in New Urban Development: A Case Study on Little India Brickfields, Kuala Lumpur. International Proceedings of Economics Development and Research, 74, 1 .

Bowen, P. A., Cattel, K. S., Hall, K. A., Edwards, P. J., \& Pearl, R. G. (2002). Perceptions of time, cost and quality management on building projects. Construction Economics and Building, 2(2), 48-56.

Game, E. T., Fitzsimons, J. A., Lipsett-Moore, G., \& McDonald-Madden, E. (2013). Subjective risk assessment for planning conservation projects. Environmental Research Letters, 8(4), 045027.

Hisham, N. A. A., \& Hassan, H. (2015). Problems in heritage building conservation. Advances in Environmental Biology, 63-67. 
Nurul Hadirah Mohd Nawi, Roziha Che Haron, \& Zumahiran Kamaruddin

Risk Cost Analysis in Malay Heritage Conservation Project

ICOMOS, A. (2013). The Burra Charter: The Australia ICOMOS charter for places of cultural significance 2013. Australia ICOMOS Incorporated.

Ismail, N., Masron, T., \& Ahmad, A. (2014). Cultural heritage tourism in Malaysia: Issues and challenges. In SHS Web of Conferences (Vol. 12, p. 01059). EDP Sciences.

Lee, Q. Y., \& Lim, Y. (2010). Preparation of tender for building conservation workcurrent practices in Malaysia. International Journal of Human and Social Sciences, 5(3), 6.

Wee, L. W., \& Lim, Y. M. (2010). Elemental cost format for building conservation works in Malaysia. Structural survey, 28(5), 408-419.

Lim, Y. M. (2017). Standard guidelines for bill of quantities customised for building conservation works: The Malaysian context/Lim Yoke Mui (Doctoral dissertation, University of Malaya).

Mbachu, J., \& Taylor, S. (2014). Contractual risks in the New Zealand construction industry: Analysis and mitigation measures. International Journal of Construction Supply Chain, 4(2), 22-33.

National Heritage Department. (2016). Garis Panduan Pemuliharaan Bangunan Warisan. Kuala Lumpur.

Rashid, S., Choo, I. A. H., Ramele, R. B., Baharuddin, M. N., \& Alauddin, K. (2018). Decorative Elements of Traditional Malay Houses: Case Study of Rumah Limas Bumbung Perak (RLBP). The Journal of Social Sciences Research, 105-115.

Rezakhani, P. (2012). Classifying key risk factors in construction projects. Buletinul Institutului Politehnic din lasi. Sectia Constructii, Arhitectura, 58(2), 27.

Roy, D., \& Kalidindi, S. N. (2017). Critical challenges in management of heritage conservation projects in India. Journal of Cultural Heritage Management and Sustainable Development,7(3), 290-307. doi:10.1108/jchmsd-03-2017-0012

Safayet, M. A., Islam, M. H., \& Ahmed, S. (2018). A Case Study on Risk Management in Existing Construction Project in Bangladesh.

Smith, J. (2005). Cost budgeting in conservation management plans for heritage buildings. Structural survey, 23(2), 101-110.

Xiang, P., Jia, F., \& Li, X. (2018). Critical Behavioral Risk Factors among Principal Participants in the Chinese Construction Industry. Sustainability, 10(9), 3158.

Zolkafli, U. K., Zakaria, N., Yahya, Z., Ali, A. S., Akashah, F. W., Othman, M., \& Hock, Y. K. (2012). Risks in Conservation Projects. Journal of Design + Built, Vol. 5(1).

Received: January 2020. Accepted: $1^{\text {st }}$ April 2020 